\title{
EDITORIAL
}

\section{ARMED FORCES TODAY}

The year 2016 is a very important year for Slovenia. It is the year in which we commemorate our decision made 25 years ago to take an independent and democratic path, a path of decisions and changes. Since then, a lot has occurred. We have gained a number of experiences, we are more skilled and more knowledgeable. On the occasion of important anniversaries, such as this one, we usually take time to appreciate the milestones which marked the path we have walked. But what is even more inspiring is that these anniversaries and historical memories can be used as a source of ideas for the future.

The editorial board of Contemporary Military Challenges set a goal to honour the twenty-five years of Slovenia's independence with this year's last number titled Republic of Slovenia - first 25 years of independence in the international security environment. In this issue we would like to include papers which reflect the knowledge of Slovenian history and experience in the field of security, defence and military, and are at the same time enriched with current topics and suggestions for Slovenia's future path in the international security environment.

The third issue which will see the light of day in October will be titled International security community at a crossroads. We expect papers on the novelties introduced by the NATO Summit in Warsaw and the new European Defence Strategy, papers regarding different current security risks and in particular papers on possible responses to such risks. The most important element of response to security risks is prevention in the form of anticipation, planning, formation and coordination of strategies and, finally, their successful realization.

The second issue in our eighteenth volume will be titled Women, peace and security on the $15^{\text {th }}$ anniversary of the UN Security Council Resolution 1325. In the past, two collections of scientific papers on women in the armed forces were published 
in Slovenia. The first was published by the Ministry of Defence in 1995, while the second is the result of cooperation of the Ministry of Defence and the Faculty of Social Sciences. However, this will be the first issue of Contemporary Military Challenges devoted specifically to this subject.

The title of this year's first issue is Armed forces today. With these selected titles and topics we will dedicate this year's issues to the past, the present, the future, to women, and to peace and security.

The first paper in the issue devoted to the armed forces today is titled Theoretical aspects of the relationship between strategy and defence planning in the securitydefence and military fields. Pavel Vuk says that "/.../ a state's investment in the development of strategic thought, planning knowledge and skills should not be the subject of calculations regarding the resources invested, but the subject of long-term investment into the development of the thinking processes, ideas about future military objectives, warfare concepts and future possibilities of the armed forces". He believes that strategy and defence planning are rightfully placed among the most important and at the same time most challenging activities of every state.

Mehmedin Tahirović and Olivera Injac present the Development of the defence system of Montenegro. In their opinion, each state has its own strategic reasons for and particularities in the search of the best model for the protection of its security. They continue with the thought that reforms and the construction of all elements of Montenegro's national security during the accession process to Euro-Atlantic structures, especially the defence system, are much cheaper and that the level of their effectiveness is much higher.

Roving defence attachés: advantages and disadvantages is the title of the paper in which Gregor Zupan highlights the working principles of defence attachés who, due to the reduction of finances and the influence of modern technologies, have mostly been assuming posts of resident or roving defence attachés in recent years. In his paper, the author reflects the positive and negative aspects of both functions, especially from the aspect of the diplomatic career path development.

Vinko Vegič writes about the Emergence and conceptualization of hybrid warfare. $\mathrm{He}$ raises the issue of defining the concept of hybrid warfare in general and on the example of Ukraine and the so-called Islamic State, and defines its basic characteristics. Later in the paper, the author addresses the possibilities and issues of confronting hybrid warfare, and stresses the necessity to reflect on what the new strategic reality, currently manifested in the phenomenon of hybrid warfare in the Eastern and Southern outskirts of NATO (Ukraine, Syria and Iraq), is bringing to Slovenia's security environment.

Echelonment of fires and indirect fire systems in the Slovenian Armed Forces is the title of the topic addressed by Viktor Potočnik. According to the author, the 
purpose of this paper is simple: to form a standpoint of the Slovenian Armed Forces regarding the role and the task of systems providing indirect fires for fire support at the tactical level, all the way from platoon to brigade level. He explains the concept of the echelonment of fires and its significance for the success of fire and manoeuvre in the battlefield. Was he successful and how did he do it? You can read more about it in his paper.

Civil-military cooperation in general, especially in NATO and the European Union, and the particularities of such cooperation among the armed forces were the focus of Maja Garb in her paper titled Development of the term and the concept of civilmilitary cooperation and coordination in peace operations. One of her conclusions is that the overview of the contents and use of the civil-military cooperation term, better known as CIMIC, shows that in the context of modern peacekeeping operations both the contents and its use are ambiguous. Moreover, there are contradictions regarding cooperation in the field, which is especially evident in the relationship between humanitarian organizations and military forces.

Andreas Hauptmann Kaiser prepared a paper titled The German armed forces mountain troops in which he presents the purpose, organization and functioning of the German mountain warfare units in detail, with special emphasis on the 23rd Mountain Infantry Brigade and the Edelweiss 2015 exercise.

As always, readers of the Contemporary Military Challenges are kindly invited to read the papers and submit their own. 